\title{
An Accounting International Experience Course
}

Leigh Redd Johnson, JD, Murray State University, USA

Holly R. Rudolph, DBA, CPA, Murray State University, USA

Robert A. Seay, DBA, CPA, Tennessee Technological University, USA

\begin{abstract}
Accounting students need practical opportunities to personally experience other cultures and international business practices if they are to effectively compete in today's global marketplace. In order to address this need, the Department of Accounting at Murray State University offers an international experience course which includes a short-term study tour of London. This paper examines the rationale for an accounting international experience course, provides an overview of the class and presents a suggested itinerary for the London trip.
\end{abstract}

Keywords: International Experience Course, Internationalization, Study Abroad, London, Accounting Program

\section{INTRODUCTION}

¿ nternationalization of the accounting curriculum has long been a topic of interest to colleges and universities and has been the subject of considerable research attention (e.g., Clay, 1975; Mintz, 1980; Palmer, Ziegenfuss, \& Pinsker, 2004; Rezaee, Szendi, \& Elmore, 1997; Sherman, 1987; Tondkar, Adhikari, \& Coffman, 1994; Tondkar, Flanigan, Adhikari, \& Hora, 1998). While approaches to internationalization have varied, most efforts have included the addition of a stand-alone international accounting course or curriculum revisions to existing courses (e.g., Intermediate, Advanced, Tax, Auditing) to include international accounting topics. This paper explains how an international experience course (IEC) can help to initiate the internationalization of an accounting program or complement existing international education efforts. The IEC approach, which involves a study tour of a foreign country, is prevalent in many college and university business programs (Finley, Taylor, \& Warren, 2007). However, application of an IEC within an accounting program is less common. This represents an outstanding opportunity for student and faculty development as well as enrollment growth.

An IEC addresses the concern that students may not be adequately exposed to out-of-classroom international experiences (Albrecht \& Sack, 2000), which are critical for effective participation in the global economy. When accounting students seek permanent employment, they find that most companies include some dimension of international business. In fact, surveys show that over sixty percent of senior executives report increased international business activity over the last five years (Experience, 2008). As a result, entry-level applicants who study abroad during college receive priority placement with a number of large accounting firms (Experience). Consequently, accounting students must be equipped to work with and within other cultures, able to travel abroad with confidence and exposed to international commerce.

An IEC within an accounting department offers students substantial benefits over a traditional study abroad program since it can be tailored to fit both departmental goals and student needs, thereby increasing participation. Many accounting majors fail to take advantage of traditional study abroad programs due to time constraints, excessive costs, student work schedules, or the need to take other experiential offerings such as internships. An IEC that incorporates a short-term study tour overcomes these challenges because it is cost efficient, does not interfere with other courses or experiential offerings, minimally disrupts student work schedules, and may be perceived by students as more relevant to their major field of study. 
While many international destinations are attractive options for a short-term study abroad experience, London offers considerable advantages for accounting students. First, it is relatively easy to get to from the east coast of the U.S. which minimizes travel time. Second, there is no language barrier which makes navigating the city and communicating with guides on excursions and hosts at sites much easier. Third, London is the financial center of Europe. More than 13,500 overseas companies from over 90 countries are based in London, and the city claims over 100 of Europe's 500 largest companies (StudyAbroad, n.d.). Fourth, London is the home of the International Accounting Standards Board and is the domicile for many public companies that have been using International Financial Reporting Standards (IFRS) for several years. Fifth, London is a very cosmopolitan city where surprisingly over 300 languages are spoken and resident communities from over 90 countries are present (StudyAbroad, n.d.). Sixth, other legendary attractions are close to the city (e.g., Oxford, Cambridge, Bath, Stonehenge, etc.). Finally, the cultural opportunities are bountiful - from theater to history to art to architecture the list is endless. For these reasons, London becomes an easy choice when selecting a destination for a short-term international study tour.

\section{PLANNING AN INTERNATIONAL EXPERIENCE COURSE}

Murray State University (MSU) has offered an IEC within the accounting curriculum for the last four years. As a central component of this course, a London study tour is organized for nine days during spring break. The Department of Accounting often works with the MSU Study Abroad Office and Cooperative Center for Study Abroad to plan certain aspects of the trip. Following are the major elements of the IEC:

Course Credit. Students generally choose to use the three-hour course as an undergraduate accounting elective to fulfill major requirements, although they may designate the class as a general business elective. This allows students to benefit from the study abroad experience while taking advantage of content-related accounting courses that will help prepare them for further graduate study and/or the CPA exam. Graduate students may elect to take the course as an elective in the Master's of Business Administration Program; however, additional deliverables are required.

Class Schedule/Format. The class meets once per week during the spring semester prior to the study tour and two times following the tour (it convenes during late afternoon hours to avoid scheduling conflicts). The discussionbased course incorporates topics related to the site visits and cultural experiences included in the tour as well as other timely international issues.

Grading. The course is graded on a pass/fail basis. Students earn a passing grade by attending and participating in all weekly preparatory and post-travel meetings, submitting acceptable course deliverables and completing the travel component of the course in a competent and professional manner.

Deliverables. Deliverables include weekly journal entries (prepared pre-trip) on a class "Wiki" website and a personal journal (submitted post-trip) based on participation in all group excursions. Students research each planned activity prior to departure and collaborate as a group to produce individual pages detailing each site visit on the "Wiki" website (we suggest using pbworks.com). Assigning Wiki pages for specific itinerary sites on a weekly basis provides a foundation for course discussion each week. A student editor (which rotates every class period) is responsible for each page, ensuring continuity and a polished finished product. At the end of the pre-travel class sessions, students have a travel guide specifically tailored for their London trip complete with appropriate questions for each site visit on the tour. Two weeks following the trip, students submit their personal journal detailing their trip experiences in narrative and pictorial format.

Cost of the Trip. The Department endeavors to limit the cost of the trip to approximately $\$ 3,000$ in order to garner broad participation among accounting students. The fee includes airfare, hotel accommodations, a tube (subway/bus) pass, alternate transportation to and from planned destinations, entrance to itinerary activities, one theater ticket and complimentary breakfast through the hotel. Students are expected to bring additional funds for other meals, non-itinerary activities and souvenirs. Many MSU students partially fund the trip through University study abroad scholarships, departmental scholarships and/or financial aid. 
Trip Logistics. The class departs for the study tour on Friday prior to the start of the University's spring break and arrives home on the last Saturday of the break. Two accounting faculty members accompany the students to England (typically one male and one female); one being the lead faculty for the trip, the other shadowing the lead faculty in preparation for the following year. Prior to departure, a required orientation session is held for students and their families to discuss security issues, insurance and health care concerns and trip rules. Detailed trip itineraries and contact information also are distributed at this meeting.

\section{LONDON SPRING BREAK STUDY TOUR ITINERARY}

Recognizing that the first and last day of the nine-day trip involves travel to and from London, the remaining seven days are planned to include the optimum blend of business and cultural experiences. The suggested itinerary for days two through eight follows. Table 1 summarizes the proposed itinerary as well as pre-travel classroom activities.

Day Two - Arrival and City Tour. The group arrives at Gatwick International Airport at approximately 6:00 a.m. on Saturday morning. After collecting luggage and going through customs, they meet their tour guide for the day. On the one-hour coach trip to London, the guide briefs the group on English customs, traditions, history, and answers questions from students and faculty members. Arriving in London early Saturday morning allows time for a brief city tour prior to checking into the hotel. One of the first stops on the London tour is the city's most famous residence, Buckingham Palace, where the class observes the Changing of the Guard, Queen Victoria Monument, and the Palace Gardens. A short walk through St. James Park, the group arrives at Westminster where they view the stately Houses of Parliament, Big Ben (the "voice of London"), and the London Eye, the highest observation wheel in the world.

The next stop on the tour is Westminster Abbey, a monastery owned by the royal family where English royalty are crowned and buried. Students are amazed at the medieval Gothic architecture of the Abbey as they tour St. Edward's Chapel, Poet's Corner, the tombs of Queen Elizabeth 1 and Queen Mary, and view some wonderful antiquities such as the Coronation Chair and $13^{\text {th }}$ century works of art. Following the Abbey tour, the group boards the coach for a short ride to the hotel located in the district of Kensington. After taking luggage to their rooms, the students meet for a brief orientation with their professors where itineraries are discussed, tube passes are distributed, and security issues are reviewed. Following a trip to the nearest tube stop for a short introduction to the transit system, students return to the hotel for some long-awaited rest or for a night out on the town.

Day Three - City Tour Continues. On the third day, the group continues the tour of London by visiting other historic venues. The first stop is a guided tour of the Tower Bridge, an architectural masterpiece built in Gothic style. The Bridge offers outstanding views of London landmarks including St. Patrick's Cathedral, Canary Wharf and the London Eye. The students take a self-guided tour of the Bridge Museum where they view the original hydraulic machinery that powered the Bridge in the late 1800s. A brief walk over the Tower Bridge, the group continues to their next attraction, the Tower of London, another Gothic- designed structure that is surrounded by a series of stone security walls and moats. The guides review the rich history of the Tower and its varied functions, including fortress, palace, prison, and home of the crown jewels. The group tours many of the buildings including the Bloody Tower and the Jewel Room and views other attractions such as Traitors Gate, ravens that protect the grounds, and Beefeaters who manage the complex. Following a lunch break at the Tower Hill Diner, the group travels by ferry down the Thames River to its next destination, Greenwich and the Royal Observatory.

The views from the Thames River provide another amazing vantage point of the east-west corridor of the city. Arriving at Greenwich, the group can select among many historical attractions including the Cutty Sark, Old War Naval College, the National Maritime Museum, and the Royal Observatory. Home to the Prime Meridian and world time, the Royal Observatory is a favorite site for the entire group. Recent renovations to the Observatory included construction of a planetarium, time gallery, and education center. Students enjoy being photographed standing with one foot in the western hemisphere and one in the east. By evening the group returns to central London by river ferry, but transportation by tube also is available. Once again, students are free to return to the hotel and turn in early or enjoy London night life. 
Day Four - Professional Visits, Tea at Harrods, and Parliament. Day Four opens with students dressed in business attire for a site visit to one of the Big Four accounting firms (visits to Deloitte, Ernst \& Young, KPMG or $\mathrm{PwC}$ are rotated each year). Arranged by MSU alumni, this site visit allows the group to explore the operations of a global accounting firm and interact with office personnel. After a tour of the offices, the class enjoys presentations from seasoned practitioners and junior staff on such international topics as the convergence to IFRS, accounting career paths in England and global economic issues. Students generally engage in a lively dialogue with partners and staff on these matters, and many ask questions regarding global career opportunities. Students may be invited to participate in an audit simulation with office staff, which serves as a topic of conversation among students for the remainder of the trip. Following a brief lunch break, the group travels by tube to Lloyds of London.

A site visit to Lloyds provides both an informative lesson on risk management and an opportunity to observe the world's largest specialty insurance market at work. Dating back to the $17^{\text {th }}$ century and housed in a coffee house, Lloyds initially insured ships and their cargo. The original Lutine Bell that notified underwriters of a ship's safe return to port is housed in the Underwriting Room. In recent years, the company has expanded its coverage of risk to include oil rigs, the world's largest banks, pharmaceutical companies, celebrity body parts and even kidnap and ransom payments. The guide for the site visit provides an overview of the specialist insurance market and accompanies the group on a tour of the building including a trip to the underwriting room where businesses from all over the world come to find insurance for a wide array of risks.

Breaking from business, the group travels by tube to Harrods Department Store for tea. The Georgian Restaurant's afternoon tea is a culinary and cultural delight. Students enjoy a three-course event, including freshly cut sandwiches, scones with cream and a dessert/pastry tray. The restaurant itself is gorgeous and compliments the overall experience. Afternoon tea offers students a chance to indulge in an English tradition as well as practice their dining etiquette among friends, a necessary skill for the novice or seasoned accounting practitioner.

Refreshed from tea, the group completes the day by heading to Parliament. Debates in both the House of Lords and House of Commons are open to overseas visitors when the Houses are sitting in session. On certain nights, either House may be in session until approximately 10 p.m. This gives students an opportunity not only to add an evening event to the itinerary but also to observe the British government in action.

Day Five - University Visit, Industry Tour, and the Theater. On the fifth day, the group travels approximately two hours west of London to visit Oxford University, the first university opened in the English speaking world. The residential college system at Oxford offers a different academic experience than most American students encounter. Specifically, students study within their designated residential college and actually graduate from their respective college, while the degree is awarded from the University. Students enjoy a tour of Christ Church, a college where visitors view sites filmed in various Harry Potter movies. Literary buffs often venture over to the Eagle and Child Pub for lunch where the Inklings writer group, which included J.R.R. Tolkien and C.S. Lewis, met once a week for over a decade to discuss literature and their own manuscripts.

From Oxford, a choice of several industry tours is available. One option is a visit to Mini Cooper, Plant Oxford. Three plants in England assemble the Mini Cooper: Plant Hams Hall, Plant Oxford, and Plant Swindon. At Plant Oxford, students observe cost accounting practices, operations management, marketing and general business concepts in action, while robots and humans work on the body's shell and assemble the final product. Since each Mini Cooper is custom ordered, students witness mass customization first hand (the possible car variations are in the trillions). The tour highlights the company's commitment to continuous improvement as employees regularly submit ideas to enhance the assembly process, and exceptional ideas are posted on the walls.

Another industry alternative in lieu of Mini Cooper is the Didcot A Power Station, a dual-fired power station that uses coal, gas and biomass to generate electricity. Business instructors can request a "Geography Tour," which focuses on the social and economic issues associated with the use of energy. Guides discuss sustainable energy sources, as well as different social approaches to energy use. Students hear how England's approach to climate change (e.g., taxes and regulation) affects the Power Station and how the Station's closure will affect Britain's economy. Students also consider the differences between environmental regulations and taxes in England and the United States. 
After a full day outside the city, the group returns to the West End of London for a light dinner and theater production. Class favorites include Wicked, Phantom of the Opera and Lion King; each of these productions offers something for everyone: elaborate sets, exciting music and interesting story lines.

Day Six - Industry Tour and Choice of Athletic Tour. In light of the differences between the U.S. and U.K. healthcare system (and the current changes to the U.S. system), a hospital tour on Day Six enables the group to consider the economic and social issues surrounding government-provided versus non-government sponsored healthcare. The class may tour a private or public hospital in London. While a private hospital tour exposes the group to the types of services that are profitable in the private sector as well as the clientele that access private healthcare in a society that provides public healthcare, a public hospital tour permits the class to examine the advantages and disadvantages of a government-run system.

A far different industry choice is Fuller's Brewery in Chiswick, a regional brewery that is an international distributor of bottled beer. Trading on the London Stock Exchange as FSTA, Fuller's brews and distributes U.K.'s leading premium cask ale, London Pride, along with other award-winning ales. The company has a rich tradition, as it has been brewing beer for over 350 years in Chiswick. During a brewery tour, students view the brewing process, and much like the Mini Cooper tour, witness the application of cost accounting practices, operations management, and other general business concepts. Students also observe the advantages and disadvantages of a business model where the manufacturer of a product operates its own retail outlets as Fuller's owns over 300 pubs. After the tour, the company provides a complementary tasting for tour participants, provided participants are over the age of 18 .

As for the afternoon, the instructor can choose one of three athletic tours to include on the itinerary: Chelsea Football Club, Wimbledon or Lord's Cricket Ground. In Fulham (located in West London and, ironically, not in Chelsea), the Chelsea Football Club plays at Stamford Bridge Football Stadium. Owned by Roman Abramovich, the Club competes in the Premier League where, historically, they have been in the top tier of English football (soccer). A tour of the 41,000 seat stadium exposes students to England's most popular sport and the economic aspects of operating a football team in Europe.

In the London suburb of Wimbledon, the All England Lawn Tennis and Croquet Club hosts the Wimbledon Championships, the world's oldest tennis tournament. Wimbledon is one of four Grand Slam tennis tournaments and the only one played on grass. Of the nineteen courts at Wimbledon, Centre Court and No. 1 Court are the two main show courts and are typically only used during the Championships. During the tour, students view Centre Court's retractable roof, which was added in 2009 to prevent rain delays. In order to raise funds for capital expenditures, the All England Club issues Debentures every five years. Debenture holders receive a pair of tickets for every day of the Wimbledon Championships during the investment term, and they are the only ticket holders who may legally sell their tickets to third parties. The majority of ticket holders obtain their tickets through a public ballot where they are randomly selected by computer.

Lord's Cricket Ground, which is owned by the Marylebone Cricket Club (MCC) and said to be the "home of cricket," is in St. John's Wood. The tour starts in the MCC Museum where students are introduced to the game (as most do not have prior experience with cricket) and its 400 year history. As the tour continues, the group visits the Long Room, where students have a panoramic view of the pitch, the player's dressing rooms and an architecturally renowned media center.

Day Seven - University Visit and Industry Tour. On Day Seven, the group once again leaves the city and travels north to Cambridge University. Cambridge, like its sister university, Oxford, uses the residential college system to educate students. Unlike Oxford, however, the town of Cambridge and the University meld seamlessly together to create a quaint experience. Students enjoy a tour of Trinity College, the chapel at King's College and the local market before heading to The Eagle for lunch, a pub where Watson and Crick announced the discovery of DNA by proclaiming that they "had discovered the secret of life."

Also located in Cambridge is the next stop on the itinerary, Marshall Aerospace. Marshall is one of Europe's leading privately owned aerospace companies which specializes in conversion, modification and maintenance of aircraft. The Marshall Group also operates worldwide in the fields of military land systems and fleet 
management and owns over 52 franchised automotive dealerships in the U.K. Upon arrival, an executive officer provides an overview of international issues that affect the company, while the group enjoys tea provided by the firm. Afterwards, the group tours the large hangers where aircraft are repaired, overhauled and upgraded.

Day Eight - Free Day. By the end of the week, students are comfortable with the city and more than ready to venture out on their own. A free day at the end of the study tour permits students to return to familiar areas of the city for further exploration or to strike out in a totally new direction. In fact, students look forward to the freedom of planning their own day after following a demanding itinerary. As a security measure, students are required to travel in pairs. Within the city, student free day favorites include visits to a museum (e.g., Tate Modern, Tate Britain, V\&A) or a London walking tour. Since the class itinerary does not include a visit to Stonehenge, Windsor and Bath, some students travel west by bus to visit these iconic locations. Finally, other students leave England altogether for a day trip to Paris or Ireland.

\section{CONCLUSION}

As business schools internationalize their core curricula and accounting departments add international content to their programs, an IEC can complement other international offerings and help prepare students for the global marketplace. The keys to a successful short-term international study tour experience are planning and flexibility. By selecting an appropriate balance of professional and cultural site visits as well as pre and post-trip assessment activities, chances for a successful class experience are heightened. Since the time frame is short, effort should be taken to maximize time to the fullest extent. With an international venue such as London, travel time may be minimized, the itinerary can be balanced with business and cultural excursions, and students may individualize their free time to explore a wide array of interests. MSU has experienced many benefits from an IEC with a shortterm study tour, including increased awareness of global opportunities and confidence regarding international travel among accounting majors. Perhaps the greatest benefit of this short-term international study tour is the excitement that it garners among participants (both students and faculty) when they return to the classroom, which often proves to be contagious! 
Table 1

\begin{tabular}{|c|c|c|c|c|c|}
\hline \multicolumn{6}{|c|}{ London Study Tour Itinerary At-A-Glance } \\
\hline Date & $\begin{array}{c}\text { Schedule / } \\
\text { Type of Activity }\end{array}$ & Site Visits & $\begin{array}{c}\text { Approximate } \\
\text { Length of Activity }\end{array}$ & $\begin{array}{c}\text { Means of } \\
\text { Travel }\end{array}$ & $\begin{array}{c}\text { Pre-Travel Classroom } \\
\text { Activities }\end{array}$ \\
\hline Day 1 - Friday & Travel & N/A & & & \\
\hline Day 2 - Saturday & $\begin{array}{l}\text { Arrival } \\
\text { London Tour } \\
\text { Hotel Check-In } \\
\text { Orientation }\end{array}$ & $\begin{array}{l}\text { Buckingham Palace, Westminster } \\
\text { Abbey, Piccadilly Circus, St. Paul's } \\
\text { Cathedral, Others }\end{array}$ & 6 hours & Coach & $\begin{array}{l}\text { Research and discuss (1) each point of interest on London tour; (2) the } \\
\text { British Monarchy and its role in British history (see } \\
\text { http://www.royal.gov.uk/); (3) the London transit system (see } \\
\text { http://www.tfl.gov.uk/modalpages/2625.aspx); and (4) the British monetary } \\
\text { system (see http://www.studyenglishtoday.net/british-money.html). }\end{array}$ \\
\hline Day 3 - Sunday & London Tour & $\begin{array}{l}\text { Tower Bridge } \\
\text { Tower of London } \\
\text { Thames River Cruise } \\
\text { Greenwich/Royal Observatory }\end{array}$ & $\begin{array}{l}1.5 \text { hours } \\
2.5 \text { hours } \\
1 \text { hour (roundtrip) } \\
3 \text { hours }\end{array}$ & $\begin{array}{l}\text { Tube and } \\
\text { River } \\
\text { Ferry }\end{array}$ & $\begin{array}{l}\text { Research and discuss (1) each point of interest on London tour and (2) } \\
\text { points of interest along Thames River between central London and } \\
\text { Greenwich. A map of the Thames River is helpful in pointing out } \\
\text { landmarks along the excursion. }\end{array}$ \\
\hline Day 4 - Monday & $\begin{array}{l}\text { Financial Services } \\
\text { Retail/Social } \\
\text { Government }\end{array}$ & $\begin{array}{l}\text { Big-4 Accounting Firm } \\
\text { Lloyds of London } \\
\text { Tea and Shopping at Harrods } \\
\text { Parliament }\end{array}$ & $\begin{array}{l}3 \text { hours } \\
2 \text { hours } \\
1.5 \text { hours } \\
2 \text { hours }\end{array}$ & Tube & $\begin{array}{l}\text { Research and discuss (1) the accounting profession in England as well as } \\
\text { convergence issues related to IFRS and general economic trends in the } \\
\text { global economy; (2) the specialty insurance market and Lloyd's role in the } \\
\text { market; (3) dining etiquette and manners/protocol related to afternoon tea; } \\
\text { and (4) the relationship between the British Monarchy, Parliament and } \\
\text { Prime Minister as well as Britain's current political parties. }\end{array}$ \\
\hline Day 5 - Tuesday & $\begin{array}{l}\text { Education } \\
\text { Automobile or } \\
\text { Energy Industry } \\
\text { Theater }\end{array}$ & $\begin{array}{l}\text { Oxford University } \\
\text { Mini-Cooper Car Manufacturer or } \\
\text { Didcot Power Station } \\
\text { Various West End Performances }\end{array}$ & $\begin{array}{l}4 \text { hours } \\
3 \text { hours } \\
3 \text { hours }\end{array}$ & Coach & $\begin{array}{l}\text { Research and discuss (1) differences between the U.K. and U.S. higher } \\
\text { education systems and academic preparation for the accounting profession } \\
\text { in the U.K.; (2) the manufacturing process and cost accounting applications } \\
\text { at Mini Cooper, Plant Oxford; (3) issues related to climate change and } \\
\text { sustainable energy and differences in the U.S. and U.K. regulations related } \\
\text { to energy use; and (4) the theater performances (see } \\
\text { http://www.londontheatre.co.uk/londontheatre). }\end{array}$ \\
\hline $\begin{array}{l}\text { Day 6- } \\
\text { Wednesday }\end{array}$ & $\begin{array}{l}\text { Healthcare or } \\
\text { Manufacturing } \\
\text { Sports }\end{array}$ & $\begin{array}{l}\text { Hospital Visit or Fuller's Brewery } \\
\text { Athletic Venues such as } \\
\text { Wimbledon, Chelsea Football } \\
\text { Stadium, or Lord's Cricket Ground }\end{array}$ & $\begin{array}{l}3.5 \text { hours } \\
3 \text { hours }\end{array}$ & Tube & $\begin{array}{l}\text { Research and discuss (1) arguments for and against socialized medicine and } \\
\text { costs associated with healthcare in the U.S. and U.K.; (2) the manufacturing } \\
\text { process and cost accounting system at Fuller's brewery; and (3) English } \\
\text { sports franchises and organizational structures of teams (private vs. public } \\
\text { ownership), player contracts, and financing strategies. }\end{array}$ \\
\hline Day 7 - Thursday & $\begin{array}{l}\text { Education } \\
\text { Aerospace }\end{array}$ & $\begin{array}{l}\text { Cambridge University } \\
\text { Marshall Aerospace }\end{array}$ & $\begin{array}{l}5 \text { hours } \\
3 \text { hours }\end{array}$ & Coach & $\begin{array}{l}\text { Research and discuss (1) the colleges within Cambridge University that } \\
\text { students plan to visit and similarities and differences between Oxford and } \\
\text { Cambridge and (2) the aerospace industry within Europe. }\end{array}$ \\
\hline Day 8 - Friday & Free Day & $\begin{array}{l}\text { Museums, Stonehenge, Bath, } \\
\text { Others }\end{array}$ & All Day & Varies & $\begin{array}{l}\text { A formal itinerary from each student on "free day" activities is required, } \\
\text { including destination, means of travel, sites to visit, and name of travel } \\
\text { partner. For walking tour ideas see } \mathrm{http}: / / \mathrm{www} \text {.walks.com/. For coach tour } \\
\text { ideas see http://www.premiumtours.co.uk/. }\end{array}$ \\
\hline Day 9 - Saturday & Travel & N/A & & & \\
\hline
\end{tabular}




\section{AUTHOR INFORMATION}

Leigh Redd Johnson (J.D., University of Kentucky) is an Assistant Professor of Business Ethics and Law in the Accounting Department at Murray State University where she teaches courses in Business Ethics, Corporate Governance and Business Law.

Holly R. Rudolph (D.B.A., Southern Illinois University at Carbondale) is a Professor of Accounting at Murray State University where she teaches courses in Intermediate Accounting, Financial Reporting and Managerial Accounting.

Robert A. Seay (D.B.A., Mississippi State University) is an Associate Professor of Accounting at Tennessee Tech University where he teaches Auditing. Prior to joining Tennessee Tech, Dr. Seay was a Professor of Accounting at Murray State University.

\section{REFERENCES}

1. Albrecht, W.S., \& Sack, R.J. (2000). Accounting education: Charting the course through a perilous future. Accounting Education Series (Vol. 16). Sarasota, FL: American Accounting Association.

2. Clay, A. A. (1975). Undergraduate international accounting education. The International Journal of Accounting, 11(1), 187-192.

3. Experience. (2008). International experience can boost career. Retrieved from http://www.experience.com/alumnus/article?channel_id=finance\&source_page=additional_articles\&article $\_$id $=$article_1223647168647.

4. $\quad$ Finley, J. B., Taylor, S. L., \& Warren, D. L. (2007). Investigating graduate business students' perceptions of the educational value provided by an international travel course experience. Journal of Teaching in International Business, 19(1), 57-82.

5. Mintz, S. M. (1980). Internationalization of the accounting curriculum. The International Journal of Accounting, 16(1), 137-151.

6. Palmer, K.N., Ziegenfuss, D. E., \& Pinsker, R. E. (2004). International knowledge, skills, and abilities of auditors/accountants: Evidence from recent competency studies. Managerial Auditing Journal, 19(7), 889896.

7. Rezaee, Z., Szendi, J. Z., \& Elmore, R. C. (1997). International accounting education: Insights from academicians and practitioners. The International Journal of Accounting, 32(1), 99-117.

8. Sherman, W. R. (1987). Internationalizing the accounting curriculum. Journal of Accounting Education, 5(2), 259-275.

9. $\quad$ StudyAbroad. (n.d.). Study abroad in london. Retrieved from http://www.studyabroad.com/pages/sitecontent/london.aspx.

10. Tondkar, R.H., Adhikari, A., \& Coffman, E. N. (1994). Adding an international dimension to upper-level financial accounting courses by utilizing foreign annual reports. Issues in Accounting Education, 9(2), 271278.

11. Tondkar, R.H., Flanigan, M. A., Adhikari, A., \& Hora, J. A. (1998). Internationalizing accounting education through an integration approach: A survey of U.S. Schools. The International Journal of Accounting, 33, 483-507. 